\title{
Upaya meningkatan kebugaran jasmani melalui circuit training
}

\author{
Latif Uki Mutaqin \\ Universitas Negeri Yogyakarta, Jl. Kolombo No. 1 Yogtakarta, 55281, Indonesia \\ Email: latifukimutaqin@gmail.com
}

\begin{abstract}
Abstrak
Penelitian ini merupakan penelitian tindakan kelas (PTK). Penelitian ini dilaksanakan dalam dua siklus, dengan tiap siklus terdiri atas perencanaan, pelaksanaan tindakan, observasi, dan refleksi. Subjek penelitian adalah Siswa Kelas VIII SMP Negeri 5 Yogyakarta yang berjumlah 32 Siswa. Sumber data berasal dari guru, siswa, dokumen dan peneliti. Teknik pengumpulan data adalah dengan observasi, wawancara dan tes. Validitas data menggunakan teknik triangulasi sumber data. Analisis data menggunakan teknik analisis deskriptif kualitatif. Prosedur penelitian adalah model spiral yang saling berkaitan. Dari hasil analisis, terjadi peningkatan yang signifikan pada prasiklus ke siklus I dan dari siklus I ke siklus II. Pada Prasiklus hasil belajarKebugaran Jasmani menggantung peserta didik kategori cukup 25,8\%, kurang $64,5 \%$ dan sangat kurang $9,7 \%$. Dalam Prasiklus jumlah peserta didik yang tuntas adalah 8peserta didik. Sedangkan padaSiklus I hasil peningkatan kebugaran jasmani peserta didik pada kategori baik sebesar $22,5 \%$, cukup $32,2 \%$, kurang $42 \%$ dan kurang sekali $3,2 \%$. Dalam Siklus I jumlah peserta didik yang tuntas adalah 17peserta didik. Dan pada siklus II hasil peningkatan kebugaran jasmani menggantung peserta didik pada kategori sangat baik sebesar 6,4\%, baik 35,5\%, cukup 38,7\% dan kurang 19,4\%. Dalam Siklus II jumlah peserta didik yang tuntas adalah 25 peserta didik. Peningkatan terjadi pada siklus I. Hasil peningkatan kebugaran jasmani meningkat walaupun belum optimal. Pelaksanaan siklus II menyebabkan hasil belajar kebugaran jasmani meningkat menjadi lebih baik. Lebih banyak siswa yang memenuhi standar ketuntasan. Selain itu tercipta proses pembelajaran yang lebih aktif, efektif, efisien, dan menyenangkan sehingga bisa mendukung suatu proses pembelajaran yang berkualitas. Kesimpulan penelitian ini adalah dengan penerapan alat bantu mampu meningkatkan hasil belajar lompat jauh gaya menggantung siswa kelas VIII SMP Negeri 5 Yogyakarta tahun ajaran 2017/2018.
\end{abstract}

Kata kunci: kebugaran jasmani, circuit training, hasil belajar

\section{Efforts to improve physical fitness through circuit training}

\begin{abstract}
This research is classroom action research (CAR). This research was conducted in two cycles, with each cycle consisting of planning, action, observation, and reflection. The research subjects were Class VIII Students of SMP Negeri 5 Yogyakarta totaling 32 students. Data sources come from teachers, students, documents and researchers. Data collection techniques are by observation, interviews, and tests. Data validity uses a data source triangulation technique. Data analysis used qualitative descriptive analysis techniques. Research procedures are interrelated spiral models. From the results of the analysis, there was a significant increase in pre-cycle to cycle I and from the cycle I to cycle II. On the Precycle learning outcomes, Physical Fitness hangs students in a fairly $25.8 \%$ category, less $64.5 \%$ and very less $9.7 \%$. In the Pre-cycle the number of students who complete is eight students. While in Cycle I the results of improving the physical fitness of students in the good category amounted to $22.5 \%$, quite $32.2 \%$, less $42 \%$ and less than $3.2 \%$. In Cycle I the number of students who complete is 17 students. And in the second cycle, the results of increasing physical fitness hang students in a very good category of $6.4 \%$, both $35.5 \%$, enough $38.7 \%$,
\end{abstract}


and less 19.4\%. In Cycle II the number of students who complete is 25 students. The increase occurred in the first cycle. The results of increased physical fitness increased although not optimal. The implementation of the second cycle causes physical fitness learning outcomes to improve for the better. More students meet the standard of completeness. In addition, a learning process that is more active, effective, efficient, and fun can be created so that it can support a quality learning process. The conclusion of this study is that the application of assistive devices is able to improve the learning outcomes of hanging style long jump VIII grade students of Yogyakarta State Middle School 5/2014 academic year.

Keywords: physical fitness, circuit training, learning outcomes

\section{PENDAHULUAN}

Tingkat kebugaran jasmani yang baik akan menjadikan seorang siswa mampu bekerja secara efektif dan efisien, tidak mudah terserang penyakit, belajar lebih bergairah dan bersemangat, serta dapat secara optimal dan mampu menghadapi tantangan dalam kehidupan baik di lingkungan sekolah maupun masyarakat. Model atau macam latihan untuk meningkatkan kebugaran ada bermacam-macam, salah satu program latihan fisik yang mudah dan tidak memerlukan waktu yang lama adalah program latihan sirkuit training.

Peserta didik pada sekolah menengah pertama pada dasarnya dapat dilihat seberapa jauh kebugaran fisiknya, mengingat sebagian besar masih dalam mas pertumbuhan baik yang laki-laki maupun perempuan. Dengan kurang tertariknya siswa terhadap kebugaran jasmani dan lebih cenderung untuk pasif dalam bergerak karena candu game dan internet, maka hasil belajar kebugaran jasmani menjadi kurang maksimal dan berpengaruh terhadap nilai akhir karena tidak tercapainya kriteria penilaian. Perlu ada terobosan yang tepat dalam masalah ini agar peserta didik lebih tertarik dalam mengikuti proses pembelaaran pendidikan jasmani terlebih untuk materi kebugaran jasmani. Untuk hasil tersebut maka pendidik memilih alternatif yang dapat dilakukan untuk memecahkan masalh tersebut dengan menggunakan cu=ircuit trainin untuk meningkatkan hasil pembelajaran.

\section{Komponen-komponen kebugaran jasmani}

Depdiknas (2003) menyatakan bahwa komponen kesegaran jasmani meliputi 8 hal yaitu: (a) Daya tahan, (b) Kekuatan otot, (c) Kecepatan, (d) Kelincahan, (f) Kelentukan, (g) Keseimbangan, (h) Koordinasi, (i) Komposisi tubuh. Komponen "motor Fitness" yang dikutip oleh Yulia (2003), seseorang terdiri dari beberapa hal yang menyangkut: (a) Koordinasi (coordination), (b) Keseimbangan (Balance), (c) Kecepatan (Speed), (d) Kelincahan (Agility), (e) Daya ledak (Power). Sedangkan menurut Rusli Rutan (2000) komponen kebugaran jasmani yang berkaitan dengan kesehatan mengandung empat unsur pokok yaitu:

1. Kekuatan otot

Kekuatan otot adalah kemampuan tubuh untuk mengerahkan daya maksimal terhadap obyek di luar tubuh. Dalam pengertian lain, kekuatan otot adalah kemampuan untuk mengerahkan usaha maksimal.

2. Daya tahan otot

Daya tahan otot mirip dengan kekuatan otot, jika dilihat dari kegiatan yang dilakukan. Cuma berbeda dengan penekanannya. Daya tahan otot adalah kemampuan untuk mengerahkan daya tehadap obyek di luar tubuh selama beberapa kali.

3. Daya tahan aerobik

Daya tahan ini disebut juga daya tahan peredaran darahpernafasan, karena berkaitan langsung dengan kemampuan jantung, paru-paru, dan sistem peredaran darah. oleh karena itu, daya tahan aerobik dapat disebut juga sebagai kemampuan tugas fisik selama waktu yang cukup lama dalam jumlah ulangan tugas yang cukup banyak.

4. Fleksibilitas

Fleksibilitas merupakan gambaran dari luas sempitnya ruang gerak pada berbagai persendian yang ada dalam tubuh. 


\section{Hakikat Sirkuit training}

Sirkuit training adalah suatu sistem latihan yang dapat memperbaiki secara serempak fitness keseluruhan dari tubuh, yaitu unsur-unsur power, daya tahan, kekuatan, kelincahan, kecepatan, dan lain-lain komponen fisik (Harsono, 2001: 21). Menurut M. Sajoto (1988: 46) mengemukakan bahwa program latihan sirkuit training berbeda dengan program-program yang telah dikemukakan terdahulu, terutama dalam segi pelaksanaannya. Dimana pelaksanaan program ini terdiri dari beberapa stasiun dan setiap stasiun itu seorang atlit melakukan jenis latihan yang telah ditentukan Satu sirkuit latihan dikatakan selesai, bila seorang atlit telah menyelesaikan latihan di semua stasiun sesuai dengan dosis yang telah ditetapkan.

Sirkuit training didasarkan pada asumsi bahwa seorang atlit akan dapat mengembangkan fitness keseluruhannya dengan jalan:

1. melakukan sebanyak mungkin bentuk latihan dalam suatu jangka waktu tertentu, atau

2. melakukan suatu jumlah bentuk latihan dalam waktu yang sesingkat-singkatnya. (Harsono, 2001)

Latihan sirkuit yang dilakukan agar hasil yang maksimal terutama untuk meningkatkan derajat jasmani maupun untuk meningkatkan prestasi olahraga, hendaknya dilakukan dengan memperhatikan beberapa variabel latihan seperti berikut:

1. Volume latihan

2. Intensitas Latihan (Intensity)

3. Frekuensi latihan

4. Overload System (Irwansyah, 2006)

\section{METODE}

Pelaksanaan tindakan akan dilakukan sebanyak 2 siklus, yang masing-masing siklus terdiri dari 4 tahapan yaitu:

1. Perencanaan,

2. Pelaksanaan,

3. Pengamatan,

4. Refleksi.

\section{HASIL DAN PEMBAHASAN}

\section{Siklus I}

Pembelajaran materi kebugaran jasmani dengan menggunakan alat bantu pembelajaran pada Siklus I adalah melakukan gerakan latihan kebugaran jasmani berupa skipping, push up, sit up dan sikap lilin. Pembelajaran materi kebugaran jasmani pada Siklus I dilakukan selama dua kali pertemuan, yaitu sesuai jadwal mata pelajaran penjasorkes kelas VIII SMP Negeri 5 Yogyakarta pada hari rabu tanggal 13 September dan 20 September 2017 di SMP Negeri 5 Yogyakarta. Setiap pertemuan dilaksanakan selama 3 × 40 menit. Pembelajaran dilakukan oleh peneliti dan guru yang bersangkutan menjadi kolaborator untuk mengobservasi proses pembelajaran.

\section{Pertemuan I}

Materi yang diajarkan pada pertemuan pertama Siklus I (Rabu, 13 September 2017) adalah gerakan kebugaran jasmani menggunakan metode circuit training. Urutan pelakasanaan pembelajaran adalah sebagai berikut:

a) Peneliti menyiapkan peserta didik dan memulai proses pembelajaran dengan berdoa dan presensi.

b) Peneliti menyampiakan tujuan pembelajaran, serta kompetensi dasar dan indikator yang harus dicapai peserta didik secara singkat.

c) Peneliti memulai proses pembelajaran diawali dengan pemanasan.

d) Peserta didik mengamati media gambar dan juga aktivitas yang diinstruksikan dan dicontohkan oleh Peneliti.

e) Peneliti memberikan rangsangan untuk mendorong peserta didik agar bertanya. 
f) Peserta didik merumuskan berbagai hal tentang kebugaran jasmani.

g) Peserta didik mencoba program latihan circuit training.

h) Peneliti merangsang peserta didik untuk menjawab pertanyaan yang ada dengan cara mendiskusikan dengan kelompoknya.

i) Peneliti memfasilitasi peserta didik untuk menyampaikan jawaban dari rumusan pertanyaan secara lisan dengan didukung oleh unjuk kerja/praktik di lapangan.

j) Peneliti memfasilitasi peserta didik untuk merekonstruksi pemikiran dan aktivitas yang telah dilakukan selama proses kegiatan belajarnya

k) Peneliti memberikan informasi mengenai pembelajaran yang akan dilakukan minggu depan.

I) Pembelajaran di akhiri dengan berdoa dan peserta didik dibubarkan untuk mengikuti pelajaran selanjutnya.

\section{Pertemuan II}

Pelaksanaan pertemuan kedua Siklus I (Rabu, 20 September 2017) peneliti melakukan tes gerakan kebugaran jasmani. Hal ini bertujuan untuk mengetahui sejauh mana perkembangan hasil belajar peserta didik. Urutan pelaksanaan pembelajaran pertemuan kedua adalah sebagai berikut:

a) Peneliti menyiapkan peserta didik dan memulai proses pembelajaran dengan berdoa dan presensi.

b) Peneliti menyampaikan tujuan pembelajaran, serta kompetensi dasar dan indikator yang harus dicapai peserta didik secara singkat.

c) Peneliti memulai proses pembelajaran diawali dengan pemanasan.

d) Peneliti memulai pembelajaran dengan mengulang materi yang telah disampaikan sebelumnya.

e) Peserta didik mengamati gerak langkah, menolak, posisi di udara dan mendarat yang dicontohkan oleh peneliti.

f) Peneliti memberikan rangsangan untuk mendorong peserta didik agar bertanya dan merumuskan berbagai masalah.

g) Peserta didik mencoba pos circuit ysng terdiri dari pos push up. Pos sit up, pos skipping, pos sikap lilin.

h) Peneliti merangsang peserta didik untuk menjawab pertanyaan yang ada dengan cara mendiskusikan dengan kelompoknya.

i) Peneliti memfasilitasi peserta didik untuk menyampaikan jawaban dari rumusan pertanyaan secara lisan dengan didukung oleh unjuk kerja/praktik di lapangan.

j) Guru memfasilitasi peserta didik untuk merekonstruksi pemikiran dan aktivitas yang telah dilakukan selama proses kegiatan belajarnya.

k) Peneliti memberikan evaluasi terhadap hasil pembelajaran yang telah diakukan.

Dalam pelaksanaan Siklus I terdapat kelebihan yang dapat dijadikan sebagai tolak ukur

keberhasilan pelaksanaan pembelajaran, adapun kelebihan dari pelaksanaan Siklus I adalah:

1) Peserta didik merasa tertarik terhadap pembelajaran materi kebugaran jasmani menggunakan metode circuit training. Karena pembelajaran menggunakan metode baru yang belum pernah diajarkan sebelumnya.

2) Banyak peserta didik sudah berani melakukan gerakan kebugaran jasmani. Hal ini disebabkan mereka merasa lebih mudah melakukan kebugaran jasmani. Semakin sering peserta didik melakukan gerakan kebugaran jasmani, maka peserta didik akan semakin meningkat derajat kebugaran jasmani.

3) Dengan menggunakan alat bantu pembelajaran, materi yang diajarkan semakin mudah terserap oleh peserta didik.

Akan tetapi dalam pelaksanaan Siklus I masih terdapat kelemahan, adapun kelemahan dan kekurangan dalam pelaksanaan Siklus I adalah:

1) Masih banyak peserta didik yang kurang memperhatikan materi yang diajarkan.

2) Banyak peserta didik putri yang malu melakukan gerakan kebugaran jasmani. 
3) Banyak peserta didik yang belum mampu melakukan gerakan kebugaran jasmani dengan sempurna.

4) Peserta didik sering lupa dan sering melakukan kesalahan gerak kebugaran jasmani.

5) Peserta didik kurang aktif bertanya sehingga masih terdapat kesalahan gerakan.

6) Terdapat beberapa peserta didik yang kurang tertarik terhadap materi yang diajarkan.

Berdasarkan hasil belajar peserta didik pada Siklus I yang belum mencapai capaian target, maka perlu dilanjutkan dengan mengadakan siklus kedua.

\section{Diskripsi Data Siklus I}

Dalam pelaksanaan Siklus I, peneliti dan guru melakukan pengambilan data. Adapun diskripsi data yang diambil terdiri dari tes kemampuan kebugaran jasmani (psikomotor) dan pemahaman konsep gerak (kognitif). Kondisi hasil belajar kebugaran jasmani Siklus I disajikan dalam bentuk tabel sebagai berikut:

Tabel 1. Diskripsi Siklus I Hasil Belajar kebugaran jasmani.

\begin{tabular}{lllll}
\hline Rentang Nilai & Ket & Kriteria & $\begin{array}{l}\text { Jml } \\
\text { Anak }\end{array}$ & Prosentase \\
\hline $91-100$ & Sangat & Tuntas & 0 & $0 \%$ \\
& Baik & & & \\
$81-90$ & Baik & Tuntas & 7 & $22,5 \%$ \\
$75-80$ & Cukup & Tuntas & 10 & $32,2 \%$ \\
$60-74$ & Kurang & $\begin{array}{l}\text { Belum } \\
\text { Tuntas }\end{array}$ & 13 & $42 \%$ \\
$<60$ & Kurang & Belum & 1 & $3,2 \%$ \\
Jumlah & sekali & Tuntas & & $100 \%$ \\
\hline
\end{tabular}

Sedangkan dalam bentuk diagram, kondisi hasil belajar Siklus I peserta didik dapat disajikan seperti berikut:

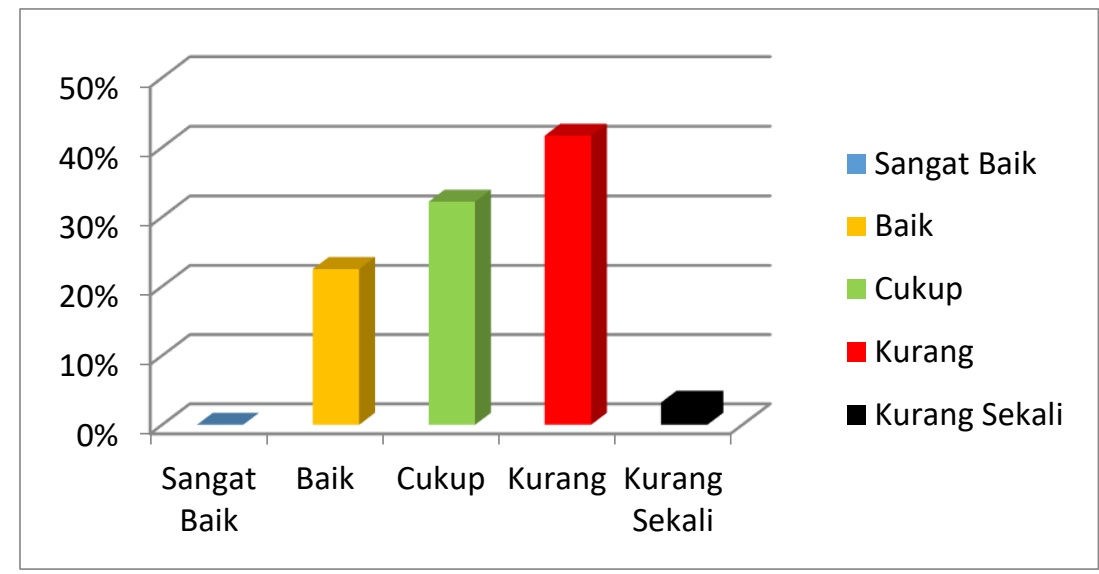

Gambar 1. Hasil Belajar Lompat Jauh Siklus I

Berdasarkan hasil diskripsi siklus pertama, hasil belajar peserta didik kelas VIII SMP Negeri 5 Yogyakarta tahun ajaran 2017/2018 adalah; baik dengan prosentase 22,5\%, cukup dengan prosentase $32,2 \%$, kurang dengan prosentase $42 \%$ dan kurang sekali dengan prosentase 3,2\%. Dari 31 peserta didik yang ada, 17 peserta didik telah mencapai kriteria tuntas sedangkan 14 peserta didik belum tuntas.

\section{Siklus II}

Siklus II adalah tindak lanjut dari hasil analisis dan refleksi yang dilakukan pada Siklus I. Dalam Siklus I peserta didik menunjukkan peningkatan hasil, namun belum semua peserta 
didik mendapat hasil yang maksimal dan belum mencapai kriteria yang ditentukan. Pelaksanaan Siklus II merupakan perbaikan dari Siklus II. Siklus II dilaksanakan selama dua kali pertemuan, yaitu sesuai jadwal mata pelajaran penjasorkes kelas VIII SMP Negeri 5 Yogyakarta pada hari Rabu tanggal 11 Oktober 2017 dan 18 Oktober 2017, di SMP Negeri 5 Yogyakarta. Setiap pertemuan dilaksanakan selama 3 x 40 menit. Pembelajaran dilakukan oleh peneliti dan guru yang bersangkutan menjadi kolaborator untuk mengobservasi proses pembelajaran.

\section{Pertemuan I}

Materi yang diajarkan pada pertemuan pertama Siklus II (Rabu, 11 Oktober 2017) adalah gerakan kebugaran jasmani menggunakan metode circuit training. Urutan pelakasanaan pembelajaran adalah sebagai berikut:

a) Peneliti menyiapkan peserta didik dan memulai proses pembelajaran dengan berdoa dan presensi.

b) Peneliti menyampiakan tujuan pembelajaran, serta kompetensi dasar dan indikator yang harus dicapai peserta didik secara singkat.

c) Peneliti memulai proses pembelajaran diawali dengan pemanasan dinamis statis.

d) Peserta didik mengamati media gambar dan juga aktivitas yang diinstruksikan dan dicontohkan oleh Peneliti.

e) Peneliti memberikan rangsangan untuk mendorong peserta didik agar bertanya.

f) Peserta didik merumuskan berbagai hal tentang kebugaran jasmani.

g) Peserta didik mencoba circuit training.

h) Peneliti merangsang peserta didik untuk menjawab pertanyaan yang ada dengan cara mendiskusikan dengan kelompoknya.

i) Peneliti memfasilitasi peserta didik untuk menyampaikan jawaban dari rumusan pertanyaan secara lisan dengan didukung oleh unjuk kerja/praktik di lapangan.

j) Peneliti memfasilitasi peserta didik untuk merekonstruksi pemikiran dan aktivitas yang telah dilakukan selama proses kegiatan belajarnya

k) Peneliti memberikan informasi mengenai pembelajaran yang akan dilakukan minggu depan.

Pembelajaran di akhiri dengan berdoa dan peserta didik dibubarkan untuk mengikuti pelajaran selanjutnya.

\section{Pertemuan II}

Pelaksanaan pertemuan kedua Siklus (Rabu, 18 Oktober 2017) peneliti melakukan tes gerakan kebugaran jasmani. Hal ini bertujuan untuk mengetahui sejauh mana perkembangan hasil belajar peserta didik. Urutan pelaksanaan pembelajaran pertemuan kedua adalah sebagai berikut:

a) Peneliti menyiapkan peserta didik dan memulai proses pembelajaran dengan berdoa dan presensi.

b) Peneliti menyampaikan tujuan pembelajaran, serta kompetensi dasar dan indikator yang harus dicapai peserta didik secara singkat.

c) Peneliti memulai proses pembelajaran diawali dengan pemanasan.

d) Peneliti memulai pembelajaran dengan mengulang materi yang telah disampaikan sebelumnya.

e) Peserta didik mengamati gerak langkah, menolak, posisi di udara dan mendarat yang dicontohkan oleh peniliti.

f) Peneliti memberikan rangsangan untuk mendorong peserta didik agar bertanya dan merumuskan berbagai masalah.

g) Peserta didik mencoba langkah circuit training

h) Peneliti merangsang peserta didik untuk menjawab pertanyaan yang ada dengan cara mendiskusikan dengan kelompoknya.

i) Peneliti memfasilitasi peserta didik untuk menyampaikan jawaban dari rumusan pertanyaan secara lisan dengan didukung oleh unjuk kerja/praktik di lapangan. 
j) Guru memfasilitasi peserta didik untuk merekonstruksi pemikiran dan aktivitas yang telah dilakukan selama proses kegiatan belajarnya.

k) Peneliti memberikan evaluasi terhadap hasil pembelajaran yang telah diakukan.

l) Pertemuan diakhiri dengan doa dan peserta didik dibubarkan.

Dalam pelaksanaan Siklus II terdapat kelebihan yang dapat dijadikan sebagai tolak ukur keberhasilan pelaksanaan pembelajaran, adapun kelebihan dari pelaksanaan Siklus II adalah:

1) Peserta didik merasa tertarik terhadap pembelajaran materi kebugaran jasmani menggunakan metode circuit training.

2) Sebagian besar peserta didik sudah mampu melakukan gerakan kebugaran jasmani. Hanya beberapa orang yang masih kesulitan dalam melakukan kebugaran jasmani.

3) Dengan menggunakan program latihan untuk pembelajaran, materi yang diajarkan semakin mudah terserap oleh peserta didik.

Akan tetapi dalam pelaksanaan Siklus II masih terdapat kelemahan adapun kelemahannya adalah masih ada sebagian anak yang tidak memperhatikan pembelajaran, masih ada peserta didik yang berbicara dengan temannya saat materi diberikan.

\section{Diskripsi Data Siklus II} berikut:

Kondisi hasil belajar kebugaran jasmani Siklus II disajikan dalam bentuk tabel sebagai

Tabel 5: Diskripsi Siklus II Hasil Belajar kebugaran jasmani.

\begin{tabular}{lllll}
\hline $\begin{array}{c}\text { Rentang } \\
\text { Nilai }\end{array}$ & Ket & Kriteria & $\begin{array}{c}\text { Jml } \\
\text { Anak }\end{array}$ & $\begin{array}{c}\text { Prosen } \\
\text { tase }\end{array}$ \\
\hline $91-100$ & $\begin{array}{l}\text { Sangat } \\
\text { Baik }\end{array}$ & Tuntas & 2 & $6,4 \%$ \\
$81-90$ & Baik & Tuntas & 11 & $35,5 \%$ \\
$75-80$ & Cukup & Tuntas & 12 & $38,7 \%$ \\
$60-74$ & Kurang & $\begin{array}{l}\text { Belum } \\
\text { Tuntas }\end{array}$ & 6 & $19,4 \%$ \\
$<60$ & Kurang & $\begin{array}{l}\text { Belum } \\
\text { Tuntas }\end{array}$ & 0 & $0 \%$ \\
Jumlah & sekali & Tut & $100 \%$ \\
\hline
\end{tabular}

Sedangkan dalam bentuk diagram, kondisi hasil belajar peserta didik dapat disajikan seperti berikut

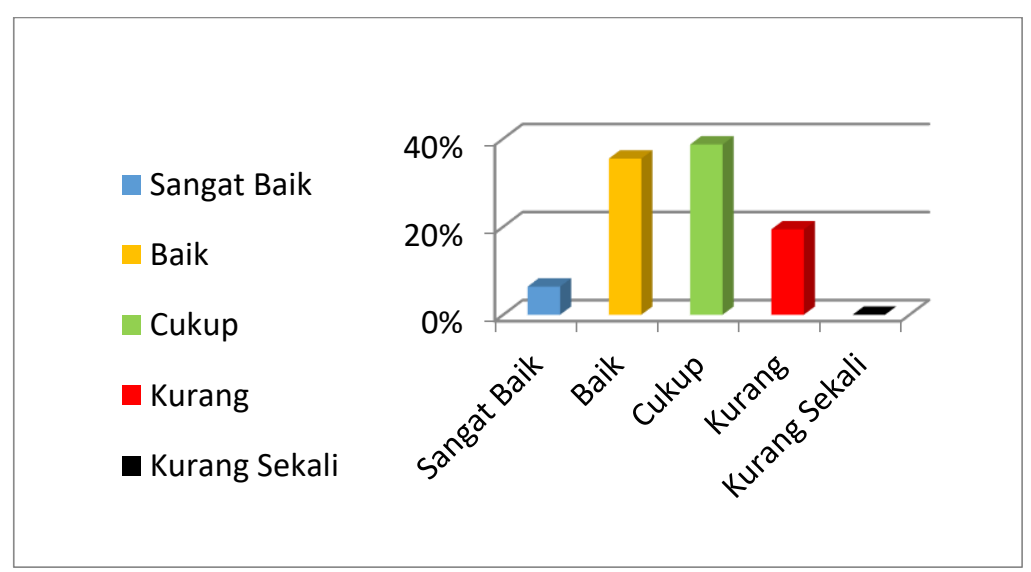

Gambar 5. Hasil Belajar Kebugaran Jasmani Siklus II 
Berdasarkan hasil diskripsi siklus kedua, hasil belajar peserta didik kelas VIII SMP Negeri 5 Yogyakarta tahun ajaran 2017/2018 adalah; sangat baik dengan prosentase 6,4\%, baik dengan prosentase $35,5 \%$, cukup dengan prosentase $38,7 \%$, kurang dengan prosentase $19,4 \%$ dan kurang sekali dengan prosentase 0\%. Dari 31 peserta didik yang ada, 25 peserta didik telah mencapai kriteria tuntas sedangkan 6 peserta didik belum tuntas.

\section{Perbandingan Hasil Tindakan Antar Siklus}

Perbandingan hasil belajar kebugaran jasmani peserta didik kelas VIII SMP Negeri 5 Yogyakarta tahun ajaran 2017/2018 pada akhir Siklus I dan Siklus II disajikan dalam bentuk tabel sebagai berikut:

Tabel 6: Diskripsi Perbandingan Hasil Belajar Kebugaran Jasmani

\begin{tabular}{clccc}
\hline \multirow{2}{*}{$\begin{array}{c}\text { Rentang } \\
\text { Nilai }\end{array}$} & Ket & \multicolumn{3}{c}{ Prosentasi } \\
\cline { 3 - 5 } & & Data Awal & Siklus I & Siklus II \\
\hline $91-100$ & Sangat Baik & $0 \%$ & $0 \%$ & $6,4 \%$ \\
& & & & \\
$81-90$ & Baik & $0 \%$ & $22,5 \%$ & $35,5 \%$ \\
$75-80$ & Cukup & $25,8 \%$ & $32,2 \%$ & $38,7 \%$ \\
& & & & \\
$60-74$ & Kurang & $64,5 \%$ & $42 \%$ & $19,4 \%$ \\
$<60$ & Kurang sekali & $9,7 \%$ & $3,2 \%$ & $0 \%$ \\
\hline
\end{tabular}

Sedangkan dalam bentuk diagram, perbandingan hasil belajar peserta didik dapat disajikan seperti berikut:

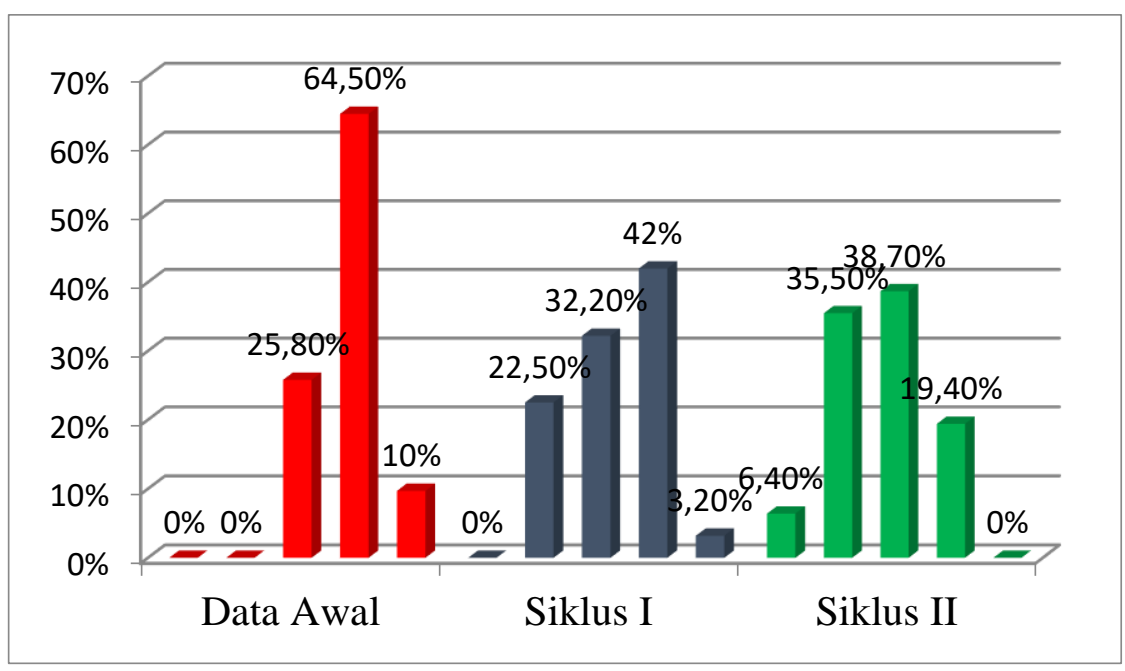

Gambar 6. Perbandingan Hasil Belajar kebugaran Jasmani

Berdasarkan hasil pelaksanaan penelitian tindakan kelas pada siklus I dan II dapat disimpulkan bahwa terjadi peningkatan hasil belajar kebugaran jasmani pada peserta didik kelas VIII SMP Negeri 5 Yogyakarta tahun ajaran 2017/2018. Dari hasil analisis, terjadi peningkatan yang signifikan pada prasiklus ke siklus I dan dari siklus I ke siklus II. Pada Prasiklus hasil belajar kebugaran jasmani peserta didik kategori cukup 25,8\%, kurang 64,5\% dan sangat kurang 9,7\%. Dalam Prasiklus jumlah peserta didik yang tuntas adalah 8 peserta didik. Sedangkan pada Siklus I hasil belajar kebugaran jasmani peserta didik pada kategori baik sebesar $22,5 \%$, cukup 32,2\%, kurang $42 \%$ dan kurang sekali 3,2\%. Dalam Siklus I jumlah 
peserta didik yang tuntas adalah 17 peserta didik. Dan pada siklus II hasil belajar kebugaran jasmani peserta didik pada kategori sangat baik sebesar $6,4 \%$, baik $35,5 \%$, cukup $38,7 \%$ dan kurang 19,4\%. Dalam Siklus II jumlah peserta didik yang tuntas adalah 25 peserta didik.

Pada Siklus I terjadi peningkatan hasil belajar kebugaran jasmani walaupun kurang signifikan. Sedangkan pada pelaksanaan Siklus II terjadi peningkatan kebugaran jasmani yang lebih signifikan. Lebih banyak peserta didik yang memenuhi standar ketuntasan.

\section{SIMPULAN}

Penelitian Tindakan Kelas pada siswa kelas VIII SMP Negeri 5 Yogyakarta tahun ajaran 2017/2018 dilaksanakan dalam dua siklus. Setiap siklus terdiri ata dua pertemuan. Dalam siklus terdapat empat tahapan, yaitu: (1) perencanaan, (2) pelaksanaan tindakan, (3) observasi dan interpretasi, dan (4) analisis dan refleksi. Dari hasil analisis data, diperoleh peningkatan yang signifikan pada siklus I dan siklus II. Hasil belajar kebugaran jasmani pada siklus I dalam kategori tuntas adalah $54,6 \%$ atau 17 siswa. Pada siklus II terjadi peningkatan prosentase hasil belajar siswa dalam kategori tuntas sebesar $80,6 \%$ atau sejumlah 25 siswa.

Dengan demikian, dapat disimpulkan bahwa alat bantu kardus dan bola gantung dapat meningkatkan hasil belajar kebugaran jasmani siswa kelas VIII SMP Negeri 5 Yogyakarta tahun ajaran 2017/2018.

\section{SARAN}

Sesuai dengan simpulan dan implikasi hasil penelitian, serta dalam rangka ikut menyumbangkan pemikiran bagi guru dalam meningkatkan proses pembelajaran, khususnya bidang studi penjasorkes, maka dapat disampaikan saran-saran sebagai berikut:

1. Bagi Guru Penjasorkes Kelas VIII SMP Negeri 5 Yogyakarta

a) Guru untuk membuat kreasi program latihan sesuai umur anak dalam mengajarkan gerakan kebugaran jasmani, agar hasil menjadi lebih maksimal.

b) Guru untuk lebih kreatif dalam membuat dan mengembangkan alat bantu pembelajaran sehingga akan tercipta pembelajaran yang aktif dan menyenangkan.

c) Guru harus memperhatikan kondisi siswa dan menggunakan strategi mengajar yang bervariasi. Sehingga motivasi dan keaktifan siswa akan meningkat pada bidang studipenjasorkes.

d) Kepada guru yang belum menerapkan penggunaan alat bantu pembelajaran hendaknya mencoba teknik tersebut dalam pembelajaran penjasorkes sehingga nantinya dapat bermanfaat untuk meningkatkan hasil belajar siswa.

2. Bagi Siswa Kelas VIII SMP Negeri 5 Yogyakarta

a) Siswa harus meningkatkan kemampuan dan juga selalu mengembangkan metode belajar untuk memperluas wawasan.

b) Siswa harus selalu mampu belajar mandiri dan mengerjakan tugas yang diberikan guru agar teknik dan gerakan menjadi lebih baik.

c) Siswa harus selalu siap dalam menerima materi yang diberikan guru dengan strategi pembelajaran apapun.

d) Siswa harus semangat dalam menerima dan melaksanakan petunjuk yang diberikan guru.

\section{DAFTAR PUSTAKA}

Arikunto, S, Suhardjono, dan Supardi. (2007). Penelitian tindakan kelas. Jakarta: Bumi Aksara. Ekawarna. (2009). Penelitian tindakan kelas. Jakarta: Gaung Persada.

Hadziq, K. (2013). Pendidikan jasmani oalahraga dan kesehatan untuk SMA - MA / SMK kelas $X$, kurikulum 2013. Bandung: PT. Yrama Widya.

Furqon, M. (2006). Mendidik anak dengan bermain. Surakarta: Universitas Sebelas Maret. Mulyasa, H. (2009). Praktik penelitian tindakan kelas. Bandung: PT. Remaja Rosdakarya.

Permendikbut tahun 2014 no 104. Peraturan menteri pendidikan dan kebudayaan Republik indonesia. 
Purnomo, E. (2011). Dasar-dasar gerakan atletik. Yogyakarta: Alfamedia.

Pardjono. (2007). Panduan penelitian tindakan kelas. Yogyakarta: Lembaga Penelitian Universitas Negeri Yogyakarta.

Saputra, Y. (2001). Dasar-dasar keterampilan atletik. Jakarta: Direktorat Jenderal Pendidikan Dasar \& Menengah.

Winarno, M. (2007). Metodologi penelitian dalam pendidikan jasmani. Malang: Universitas Negeri Malang. 